\title{
CLINICAL CASE STUDIES IN MENTAL HEALTH BY MEANS OF THE ON-LINE DISCUSSION
}

\author{
Edilaine Cristina da Silva ${ }^{1}$ \\ Antonia Regina Ferreira Furegato ${ }^{2}$ \\ Simone de Godoy ${ }^{3}$
}

Silva EC, Furegato ARF, Godoy S. Clinical case studies in mental health through on-line discussion. Rev Latinoam Enfermagem 2008 maio-junho; 16(3):425-31.

This descriptive and exploratory study with a qualitative design aimed to describe and analyze discussions in online chats about mental disorders in a psychiatric nursing course as part of an undergraduate nursing program. The sample consisted of 32 undergraduate students who attended the course. Data analysis showed that the discussions through online chat sessions permeated the acquisition of knowledge, procedures, attitudes and values and promoted students' active participation. The results reaffirm the discussions' importance for students' learning and showed the potential of technology resources, such as real-time communication tools, to support and improve teaching possibilities in psychiatric nursing.

DESCRIPTORS: psychiatric nursing; teaching; education

\section{ESTUDIOS DE CASOS CLÍNICOS EN SALUD MENTAL MEDIANTE DISCUSIÓN EN-LINEA}

Estudio descriptivo y exploratorio con enfoque cualitativo con el objetivo de describir y analizar discusiones en-línea sobre casos clínicos, como parte de la disciplina de Enfermería Psiquiátrica. La muestra formada por 32 alumnos que cursaban la asignatura. El análisis de los datos mostró que las discusiones a través de las conversaciones en-linea favorecieron el aprendizaje, procedimientos, actitudes y valores; promoviendo la participación activa de los estudiantes. Los resultados fundamentan la riqueza en la discusión, para el aprendizaje del estudiante, así como evidencian la potencialidad para el uso de herramientas tecnológicas, como las de comunicación en tiempo real, para apoyar e incrementar las posibilidades educativas en enfermería psiquiátrica.

DESCRIPTORES: enfermería psiquiátrica; enseñanza; educación a distancia

\section{ESTUDOS DE CASOS CLÍNICOS EM SAÚDE MENTAL POR MEIO DE DISCUSSÃO ON-LINE}

Estudo descritivo e exploratório, com abordagem qualitativa, cujo objetivo foi descrever e analisar discussões de casos clínicos on-line na disciplina de Enfermagem Psiquiátrica do Curso de Graduação em Enfermagem. A amostra constituiu-se de 32 acadêmicos de enfermagem que cursavam a disciplina. A análise dos dados evidenciou que as discussões, através do bate-papo, permearam a aprendizagem de conhecimentos, procedimentos, atitudes e valores e promoveram a participação ativa dos estudantes. Os resultados reforçam a riqueza da discussão para a aprendizagem do estudante e evidenciam a potencialidade do uso de recursos tecnológicos, como as ferramentas de comunicação em tempo real, para apoiar e incrementar as possibilidades educativas em enfermagem psiquiátrica.

DESCRITORES: enfermagem psiquiátrica; ensino; educação à distância

${ }^{1}$ Ph.D., Faculty, e-mail: nane@eerp.usp.br; ${ }^{2}$ Full Professor, e-mail: furegato@eerp.usp.br; ${ }^{3}$ Laboratory Specialist, e-mail: sig@eerp.usp.br. University of São Paulo at Ribeirão Preto College of Nursing, WHO Collaborating Centre for Nursing Research Development, Brazil 


\section{INTRODUCTION}

Mental health care is addressed in nursing training, with strategies for undergraduate education as the great allies. Investments in training directly affect professional performance, guaranteeing greater quality in integral care.

Nurses consider that undergraduate courses do not construct the skills needed for work in psychiatry and mental health. Thus, they seek specialization courses as the alternative to solve the lack of competencies in this area ${ }^{(1-2)}$.

The deficiency in the construction of skills for practical performance in psychiatric nursing seems to be related to students' difficulty to mobilize their own resources and the knowledge acquired through formal education in real situations ${ }^{(2)}$. Research carried out with nurses suggests that mental health actions are related with professional training, indicating the need to grant more importance to continued and undergraduate education actions ${ }^{(3)}$.

Teaching directed at the construction of skills aims for a didactic transposition, based on a prospective and realistic analysis of situations in life, where the school prepares students or professionals for the diversity of the world, uniting knowledge, savoir-faire, attitudes and values in the multiple situations of daily life ${ }^{(4)}$.

Thus, learning for competency development considers the components of Knowing (declarative knowledge), Doing (skills) and Knowing How To Be (attitudes and values). In this sense, psychiatric nursing aims for learning from the perspective of human development, oriented towards action and social awareness, supported by the pillars of education, integrating all these components ${ }^{(5)}$.

In view of the immediate need for revision and questioning of psychiatric nursing teaching, new education strategies are needed which aim for the transformation and favoring of professional skills.

The use of technological resources has been frequently presented in the current context of nursing education ${ }^{(6)}$. This reality cannot be ignored by nursing teachers, but should be used in favor of the development of new education perspectives in the area.

The use of the virtual environment Teleduc in nursing education reflected in higher averages and higher levels of correct answers to essays questions for the group that used this technology, which the students assessed positively ${ }^{(7)}$. Studies on the use of technology in nursing education point out the improvements resulting from the insertion of new information and communication technologies for the nursing training process ${ }^{(6,8-9)}$.

In distance courses, the adoption of a theory or creation of activities that consider several currents directly interferes in the contents, activities, interaction among the participants and flexibility to consider the context of the student, creating the particularitity and quality of the teaching-learning process ${ }^{(10)}$. When linking a technology to a pedagogical model in education, it is essential to analyze the results of this combination, in order to guarantee the learning objectives and contribute to improvements in technology-mediated education processes.

\section{OBJECTIVE}

This study aimed to describe and analyze, from the perspective of human development, on-line clinical case discussions among nursing students in the Psychiatric Nursing course.

\section{MATERIAL AND METHOD}

Study design

Descriptive and exploratory study with a qualitative approach, which aims to observe, describe and explore aspects of a research situation.

Place and sample

The sample was composed of 32 students who participated in the On-Line Course on Mood and Personality Disorders. They were students from a Nursing Bachelor Program taking the Psychiatric Nursing course at a public university in São Paulo State, from August to September 2006.

Data collection

Dates and times were set for each group of students, who received the clinical case by email, with a view to discussions carried out through the chat tool that allows the participants to send and receive messages in real time. In total, five chat sessions were carried out, with the participation of a psychiatrist specialized in the subject, two tutors from the on-line Course and 12 to 15 students per session. At the end of the session, the virtual environment permitted the visualization and printing of the discussion, including all messages sent. 
Data analysis

The messages contained in the printed discussions were submitted to thematic content analysis, organized in categories constructed in accordance with the pillars of education ${ }^{(5)}$ and discussed in the light of literature on the subject.

Ethical procedures

The project was approved by the Research Ethics Committee at the University of São Paulo at Ribeirão Preto College of Nursing. The participants, duly informed, signed the Free and Informed Consent Term when they participated in the presentation of the course and this research, as recommended by resolution CNS 196/96.

\section{RESULTS AND DISCUSSION}

The content of the discussions held in the five chat sessions constituted three analytic categories, based on the education support pillars ${ }^{(5)}$ : Learning of knowledge (know), Learning of procedures (knowhow) and Attitudinal learning (attitudes and values).

Learning of knowledge (to know)

The learning of knowledge, or learning to know, is related with the possibility of addressing concepts and classifications of one specific subject in depth, combined with the individual's knowledge and general culture, in order to benefit from the opportunities education offers across life ${ }^{(5)}$.

The students' need to initially know how to define the illness (diagnosis classification) and then advance in care permeated the case discussions during all chat sessions.

Is the diagnosis really borderline? (E9)

How can we give this diagnosis? (E1)

Students compare the symptoms presented in the clinical case with their personal experiences, in the attempt to establish a limit for the revealed alterations.

But which is the limit for this diagnosis? Because I am very impulsive and explosive also, when can we know if it became pathological? (E15)

The subdivisions of disorders appear, denoting the need to establish a classification system that considers the types and intensity of the symptoms.

How could his depression be classified? (E17)

But, with these symptoms, it can already be moderate depression, can't it? (E27)
The needs the students manifested give teachers the opportunity to introduce the pathology definitions in study, motivating the students' interesting to involve them in the quarrel. With tranquility, the teacher will be able to develop the contents in accordance with the movement constructed by the group of students during the discussion, turning learning more significant and increasing the importance of each element's participation in learning.

In the following step, because they are feeling more experts of the subject in quarrel, the students tried to enumerate the illness manifestations. They indicated behaviors and they made questions to confirm the knowledge that they had acquired in the theoretical and practical activities.

I have noticed that borderline patients do not like to be opposed, do they? (E3)

They have difficulties to dealing with the limits... the rules. (E27)

They also have low tolerance to frustration. (E21)

These people don't have control of the situation when they notice they already had made. (E9)

They are hyper sexualized. (E26)

They try to affirm themselves all the time. (E28)

They possess intense and unstable relationships. (E2)

Incautiousness of clothes, fatigue. (E29)

Lack of taking care of themselves, social isolated. (E1)

At the symptoms discussions, students expressed their concern with the aggressiveness revealed by psychiatric patients.

They use to be aggressive? With their relatives? (E10)

Aggression is more verbal or it can become physical? (E17)

Can they attack the people physically? (E31)

Because they are learning different disorders at the same time, those have similar symptoms, the student try to distinguish the clinical manifestations from each one of the mental illness.

Is it the superiority trace with the other people characteristic of this type of disorder? Or is it only of the maniac? (E15)

In some depression cases, the patient also has hallucinations. (E11)

The ranks made by the students about the illness clinical manifestations are proceeding from different sources of information, such as, the informal material of the course, quarrels in the services of practical activity, commentaries with professors and other students, and others information way. In these terms, the professor should confirm the correct 
information, to correct and to lead to the agreement of the incorrect or distorted information. Moreover, the professor must lead the quarrel to make the students able to arrive at some consensus by themselves, and than complete the information and correcting lacks and excess.

During the on-line discussion several cases and examples from students' experience with the mental illness had been portrayed.

We had patients who had this diagnosis questioned in the Emergency Service (E15)

I think that the A. (patient) in the Hospital Santa Teresa he was borderline. (E25)

I met this kind of patient in the period of training. (E11)

I took care of a patient in the medical clinic. She had diabetes and also had this mental disorder. (E18)

We always received patients with this mental problem at the emergency unit... but we stabilized and only referred them to another place. (E24)

The scenarios for students' experience exceed the limits of the training areas; including family groups, neighbors and television.

I know how it is; my father had a very severe depression. (E2)

I am sure that my father has this disorder. (E7)

My neighbor lost the guard of her children because she couldn't take care of them. (E21)

Does Vera Fischer (famous actress) have a personality disorder? (E16)

Association between learning contents and personal experiences evidences how students grant new meanings to the knowledge and can be considered a parameter for the good development of the teaching-learning process.

Establishing the veracity and understanding of mental disorders supports the students' search for treatment forms.

But what is generally used? (E17)

Which kind of treatment is considered? (E8)

Which treatment is more appropriate? (E30)

It must be considered that students possess some knowledge about what they are trying to argue.

Is the treatment similar with euphoric treatment? (E22)

Is the psychotherapy effective? (E27)

Generally, the most common temporary collateral

effects are: migraines, sleeplessness, nervousness, nausea and diarrhea. (E6)

Questions that involve pharmacological treatment of mental disorders were evidenced in students' statements.
What types of medicines are used for the treatment? (E23)

Do they already begin with pharmacological treatment? (E6)

Which pharmacological treatment? Are mood stabilizers appropriate for this case? (E7)

But there are some medicines to associate, which help the antidepressive agent, aren't there? (E31)

Does pharmacological treatment work? I mean, in extreme cases? (E23)

At a specific moment, some students propose to broaden the discussion about treatment forms.

Hey guys, there does not only exist pharmacological treatment, we should use the opportunity to discuss about other therapies that helps the patient and a lot! (E4)

I agree with E4. Other strategies besides pharmacological treatment should be created, we are giving too much importance to medicines. (E15)

After that intervention, a discussion started about other forms of treatment, indicating that the group agreed with the presented proposal.

Is it true that the best treatment for severe depression is ECT (electroconvulsive therapy)? (E10)

Would it be good to include psychotherapy, besides pharmacological treatment? (E15)

In the lightest cases, psychotherapy is enough, isn't it? (E4)

Medicines and psychotherapy make the patient gain control over their impulsive attitudes. (E32)

Some students established a balanced opinion about the use of different treatment modes.

In my opinion, it is essential to start the pharmacological treatment as soon as possible to diminish these symptoms, such as fatigue, lack of concentration and the desire to take care of oneself and to start a psychotherapy for him to create meaning for everything that is happening, to try to solve problems at work and with his wife in a more healthy way. (E12)

During professional training, nurses face strong influences from the biomedical model. This influence is starting to be transformed mainly in psychiatric nursing and mental health courses $^{(11)}$.

Learning of procedures (know-how)

Learning savoir faire (know-how) aims at the development of skills that can enable a person to face countless situations, to intervene and modify reality ${ }^{(5)}$.

In this category, statements were related to the student's need to seek patient management abilities with a view to professional practice.

How can this patient be approached better? (E23) 
Should this regret always be analyzed? How can one know if it is real? If it is not part of the seduction, of the manipulation? (E17)

It must be very difficult to deal with the patients' seduction normally, mustn't it? What is that like? (E16)

Professionals must be very focused on their work not to be manipulated. (E25)

It is important to make the patient reflect on his attitudes. (E22)

When the patient becomes attached to a health professional, he must take distance and pass the case to another professional or not? (E20)

Is it difficult to make this patient acknowledge his illness? (E4)

How can I deal with his irritation, his impatience? (E31)

Professor, what do you think about using a notebook to alleviate the patient's tensions? (E8)

When a person gets mentally ill, this generally represents a great shock for the family, and its members are hardly prepared to face the consequences and to deal with the sick member ${ }^{(12)}$. In the students' opinion, the family is an important factor in the treatment of patients with mental disorders.

The treatment involves the family. (E14)

The family must be followed, because it would be a support for the patient. (E6)

I believe that the family can help. (E9)

They know that family members have difficulties and are unprepared to live with the mental illness.

The relatives face quite a lot of difficulties. (E22)

Like any family in which a member is suffering mental health problems, they need help. (E2)

Therefore, I think the family must be attended as well the patient. (E18)

The family is definitely fragile, but I believe that it is a really important help for the patient. (E4)

When families seek help in mental health services, they tell about their difficulties to deal with the crises and the complex relationship with the mental patient, besides feelings of guilt, frustration and pessimism. The relatives can face material difficulties, social isolation and insecurity in view of the illness ${ }^{(13)}$.

Students feel involved with the problem and search ways to work with the mentally ill person's family.

How can one work with whom is close, the family?
Are families advised to know how to deal with these people? How do they usually react towards the patient? (E20)

How can I make the family not face the disease with revolt or lack of goodwill? (E11)

Families must be advised so as to understand the patient's attitudes, not take it personal and get upset. (E13)

The procedure, product of the learning, occurs because of the capacity to organize actions to reach a goal. In this perspective, the acquisition of procedural knowledge consists in moving from the condition of knowing how to say to knowing how to do ${ }^{(13)}$.

To address procedural knowledge, based on the need the students manifest, turns learning most significant. Teachers are responsible for acknowledging this implicit need in the students' statements for the development of practical abilities.

Learning attitudes and values (knowing how to be)

Learning how to be is related with the growing development of autonomy, discernment and personal responsibility, culminating in attitudes and values coherent with the principles and duties of the profession.

The defined attitudinal knowledge in the course study plan expected the student to develop empathy and understanding of patients with mood and personality disorders, mobilizing them to identify necessities and to develop therapeutic actions through the interpersonal relationship.

Attitude appears from the way someone evaluates an object, a person, a fact or a situation and it is constituted by behavioral, affective and cognitive components. The congruence of these factors guarantees the consistency of one specific attitude $^{(14)}$

When advancing in the discussion, the students' affective components were mobilized by the manifestations of the mental illness.

(...) for them it must be difficult to deal with that. (E23)

(...) it is very overwhelming to see a close person with modified behavior, worse when we do not have an 'explanation'. (E18)

The person becomes more afraid of being alone, but does not know to deal with the illness either! Therefore, they need support, like any another illness (...). (E2)

I think that these people affect the professionals more, I do not know if it is my impression, but they must be one of the most difficult cases to deal with... (E24) 
These situations must be really complicated when you don't have support ... (E19)

I think they do not manipulate because they want to...

it is the way they can deal with their lives. (E21)

It must be hard for the person, to behave like this all the time. (E15)

It is very difficult to have to control oneself to please other people all the time, impossible! (E5)

It is a life of great suffering. It must be difficult to establish relationships. (E4)

In these cases, it is very difficult to accept that they are sick. (E27)

Brazilian students reveal to be less authoritarian, restrictive and discriminating towards patients with mental disorders. Moreover, they enter the job market with more positive attitudes than Chilean and Peruvian students ${ }^{(15)}$.

In this perspective, mobilization of affective components contributes to determine professional attitudes, where students develop empathy and understanding of the patient as a human being.

I gave advice about the disorder and finally convinced him to go to the doctor. (E16)

Wouldn't it be interesting to use group therapy? (E17)

We could use psychoeducation! (E12)

I think all families should receive the same orientation and support from the entire team. (E9)

We are at the end of the course and now I can say on behalf of the group that we no longer feel that FEAR of the psychiatric patients we used to feel... after the periods of training and experience involving these patients. (E4)

It is important to advise the family and the patient about the illness and the proposed treatment. (E30)

Students acknowledge the importance of the profession and start to create more awareness and responsibility for care. It means they are acknowledging the importance of their professional performance in the health team to take care of patients with mental disorders.

The greatest technical resource we have in psychiatry is ourselves. (E12)

I believe well trained nursing professionals can develop quite efficient work with borderline patients individually and with the family as well. (E11)

I think we should not take distance, but impose limits. (E24)

I believe that weekly nursing consultations would be extremely important. (E5)

For teachers, this is the opportunity to start discussing the students' feelings about the disease, as well as the values and ethical principles of the profession.

\section{FINAL CONSIDERATIONS}

The analysis showed three aspects of the nursing students' learning in the Psychiatric Nursing course through the virtual discussions of mental disorder cases by chat: learning of knowledge, learning of procedures and learning of attitudes and values.

In the learning of knowledge (knowing), the definition and classification of the disorders were highlighted, the symptoms and manifestations of the disease, personal and professional experiences, aggressiveness and kinds of treatment.

In the learning of procedures (know-how), the management of psychiatric patients and actions directed at the patients' family were highlighted.

As to the learning of attitudes and values (knowing how to be), the mobilization of affective components in view of the mental patient stood out, as well as the development of empathy, conscience and responsibility in psychiatric nursing care.

The clinical case discussions held through the chat indicated the importance of students' active participation in the teaching-learning process, valuing the pedagogical strategies used for this purpose.

In virtual discussions, chatting is considered a more direct and "real time" form to communicate than other virtual communication tools, which contributes to reduce possible emotional barriers in students (16). In this study, the analyzed discussions indicate mobilization of different student aspects related to learning, such as previous knowledge, personal and social doubts, experiences with the subject, feelings and distress.

In general, educational technologies constitute increasingly elaborated resources that support the learning processes. The most important characteristic of these resources is considered to be the possibility to work with different pedagogical references. In this sense, the present study evidenced the use of the virtual environment for psychiatric nursing learning from the perspective of human development, guided towards action and the social conscience, sustained by the pillars of education.

Moreover, results highlight the wealth of the discussion for student learning and the potential of using technological resources, such as real-time communication tools, to support and develop education possibilities in psychiatric nursing. 


\section{REFERENCES}

1. Furegato ARF, Saeki T. Formando especialistas em enfermagem psiquiátrica e saúde mental por mais de duas décadas. Cadernos IPUB 2000; 6(19):128-41.

2. Lucchese R. A enfermagem psiquiátrica e saúde mental: a necessária constituição de competências na formação e na prática do enfermeiro. [tese]. São Paulo (SP): Escola de Enfermagem da USP; 2005.

3. Silva $M C F$, Furegato $A R F$, Costa ML Júnior. Depressão: pontos de vista e conhecimento de enfermeiros da rede básica de saúde. Rev Latino-am Enfermagem 2003 janeiro-fevereiro; 11(1):7-13.

4. Perrenoud P. Construir as Competências desde a Escola. Porto Alegre: Artmed; 1999.

5. Delors J, coordenador. Os quatro pilares da educação. In: Educação: um tesouro a descobrir. São Paulo: Cortezo; 1999. p. 89-102.

6. Godoy S, Mendes IAC, Hayashida M, Nogueira MS, Alves LMM. In service nursing education delivered by videoconference. J Telemedicine and Telecare 2004; $10(5): 303-5$.

7. Jaques $A E$. Utilização de recursos tecnológicos aplicados ao ensino-aprendizado em enfermagem. [Dissertação]. Santa Catarina (SC): Universidade Federal de Santa Catarina; 2003. 8. Simpson, R.L. See the future of distance education. Nurs Manage 2006 fevereiro; 37(2):42.

9. Singleton $A B$, Clark ED. A comparison of critical thinking skills for advanced practice nursing students in traditional and distance learning cohort formats. [Dissertação] Columbia (USA): University of Missouri; 2005.

10. Leidner DE, Jarvenpaa SL. The use of information techonology to enhance management school education: a theoretical view. MIS Quartely 1995 September; 265-91.

11. Campoy MA, Merighi MAB, Stefanelli MC. O ensino de enfermagem em saúde mental e psiquiátrica: visão do professor e do aluno na perspectiva da fenomenologia social. Rev Latinoam Enfermagem 2005 março-abril; 13(2):165-72.

12. Melman J. Família e Doença Mental: repensando a relação entre profissionais de saúde e familiares. São Paulo: Escrituras; 2001.

13. Colvero LA, Ide CAC, Rolim MA. Família e doença mental: a difícil convivência com a diferença. Rev Esc Enferm USP 2004; 38(2): 197-205.

14. Pozo JI. Aprendizes e mestres: a nova cultura da aprendizagem. Porto Alegre: Artmed; 2002.

15. Pedrão LJ, Galera SAF, Silva MCP, Gonzalez AC, Costa ML Jr, Souza MCBM, Senmache GU. Perfil das atitudes de formandos em enfermagem frente aos transtornos mentais no Brasil, Chile e Peru. Rev Latino-am Enfermagem 2005 maio-junho; 13(3):339-43.

16. Laaser W. Seminarios Virtuales: Cómo aplicarlos en educación a distancia. Rev Ibero-Am Educ Distancia 1999; 2(2):151-63. 